\title{
Feeding extinction: navigating the metonyms and misanthropy of palm oil boycotts
}

\author{
Hannah Fair ${ }^{1}$ \\ University of Oxford, UK \\ Preprint Sept 2021
}

\begin{abstract}
Among UK-based orangutan conservation supporters, palm oil consumption boycotts are widespread, due to the ecological impacts of oil palm cultivation on orangutan habitat. Yet these boycotts are largely at odds with the stances of orangutan charities. Drawing on interviews with orangutan supporters, this article explores why some Global North consumers are so consumed by palm oil. Palm oil is viewed by orangutan supporters as insidious, invasive and cheap and forces a bodily complicity with orangutan suffering. It is mobilized as a metonym for human greed and capitalist destruction. This metonymic relationship mirrors broader Anthropocenic framings of human-nature relations, which emphasize humanity as a universal actor. Yet the practices of 'species guilt' associated with these framings largely mitigate against a decolonizing model of conservation, as they have the potential to deny agency to workers and villagers enmeshed within the oil palm economy. Despite these unpromising circumstances, this article explores the unintended value of palm oil boycotts in terms of agency and ecological consciousness and addresses the potential to align such boycotts with a decolonial analysis, through centering the human dimensions of orangutan conservation.
\end{abstract}

Keywords: orangutan, decolonizing conservation, ethical consumption, boycott, palm oil, Anthropocene

\section{Résumé}

En raison des impacts écologiques de la cultivation des palmiers à huile sur l'habitat des orang-outans, de nombreux boycotts de consommation d'huile de palme ont été déclarés par des défenseurs des orang-outans au Royaume-Uni. Cela dit, ces boycotts vont largement à l'encontre des positions des organismes de bienfaisance qui défendent les orang-outans. Le présent article prend comme départ un ensemble d'entrevues avec des défenseurs d'orang-outans afin d'explorer la fixation de certains consommateurs du Nord global sur l'huile de palme. Perçue par ces défenseurs comme étant insidieuse, invasive et de mauvaise qualité, l'huile de palme inspire une certaine " complicité corporelle » avec la souffrance des orang-outans. Elle est ainsi mobilisée comme métonymie pour la cupidité humaine et l'oeuvre destructrice du capitalisme, miroitant ainsi l'emphase conceptuelle de l'Anthropocène sur l'humain en tant qu'acteur universel. Cependant, les pratiques de «culpabilité de l'espèce » qu'engendrent ces concepts peuvent faire déraper un modèle de conservation décolonial en niant potentiellement aux travailleurs et aux villages intégrés dans l'industrie de l'huile de palme leur propre pouvoir. Cet article examine la valeur inattendue des boycotts de l'huile de palme malgré ces circonstances compromettantes en considérant leur potentiel vis-à-vis la conscience écologique et le pouvoir personnel. Il considère la possibilité d'aligner de tels boycotts avec une analyse décoloniale en recadrant les dimensions humaines de la protection des orang-outans.

Mots-clé: orang-outans, conservation décoloniale, consommation éthique, boycott, huile de palme, Anthropocène

\footnotetext{
${ }^{1}$ Dr Hannah Fair, Departmental Lecturer in Human Geography, University of Oxford, UK. Email Hannah.fair "at" ouce.ox.ac.uk. Acknowledgements: This research was funded by a European Research Council Starting Grant (no. 758494), and originally presented as part of the 2019 'Conservation, Climate Change and Decolonization' workshop held at ICTA, Universitat Autònoma de Barcelona. Many thanks to the two orangutan charities and many interviewees whose collaboration made this research possible, to the special issue editors for their comprehensive feedback and support, to the $J P E$ editor, and to the anonymous reviewers for their positive and insightful comments. This is the $\mathrm{xx}$ article in Dan Brockington, Esteve Corbera and Sara Maestre (eds.). 2021. "The challenges of decolonizing conservation", Special Section of the Journal of Political Ecology 28.
} 


\section{Resumen}

Entre los partidarios de la conservación del orangután en el Reino Unido, los boicots al consumo de aceite de palma están generalizados, debido a los impactos ecológicos de este cultivo en el hábitat de los orangutanes. Sin embargo, estos boicots contradicen en gran medida las posturas de las ONGs que trabajan para la conservación de dicha especie. Basándome en entrevistas con partidarios de la conservación del orangután, este artículo explora por qué algunos consumidores del Norte Global están tan en contra del aceite de palma y porqué es visto como como un cultivo y producto insidioso, invasivo y barato, que les obliga por tanto a ser compasivos con el sufrimiento del orangután. El aceite de palma se moviliza pues como metonimia de la codicia humana y la destrucción capitalista, que a su vez representa un mundo en el que la humanidad es un actor universal y central en las relaciones sociedad-naturaleza. Sin embargo, dicha movilización niega la agencia de los trabajadores y aldeanos involucrados en la economía de la palma aceitera y reifica un modelo de conservación basado en especies emblema que limita a su vez la emergencia de un modelo de conservación descolonizante. El artículo permite reflexionar sobre el valor involuntario de los boicots al aceite de palma en términos de agencia y conciencia ecológica y discute el potencial de alinear tales boicots con un análisis descolonial, al enfatizar el papel que juega lo humano y lo local en la conservación de los orangutanes.

Palabras clave: orangutan, conservación descolonizante, consumo ético, boicot, aceite de palma, el Antropoceno

\section{Introduction}

The poor things have got nowhere else to go. What are they supposed to do? It makes my blood boil, especially when palm oil is so unnecessary. (Interview 30)

In Britain, in November 2018, the plight of the orangutan (the 'poor things' in question) and the moral condemnation of palm oil went viral. Budget supermarket Iceland attempted to repurpose an existing Greenpeace video as their Christmas commercial, in order to advertise their intention to remove palm oil from all their own brand products. This commercial featured adorable, animated baby orangutan 'Rang Tan' who recounts the loss of their family and destruction of their forest home by loggers intent on developing new oil palm plantations. In actuality, the advert was never broadcast on British television due to prohibitions by Clearcast, an NGO that pre-approves UK advertisements, to ensure they are not offensive, misleading or harmful. Yet the video witnessed immense online circulation, with 65 million views across Facebook, Youtube and Twitter (Hickman, 2018), whilst a change.org petition calling for Clearcast's decision to be overturned received over one million signatures (Change.org, n.d.). Some 14 months after the incident, signatures were still accumulating daily. This video captured and engendered further outrage at the actions of palm oil companies, highlighted the everyday complicity of British consumers, and increased financial compassion for the affected orangutans, often expressed through virtual 'adoptions' where supporters make donations to a charity ostensibly in aid of an individual named ape. Immediately post-Rang Tan, WWF's virtual orangutan 'adoptions' increased 300\% compared with the previous year and their stock of cuddly orangutan toys was almost entirely exhausted (The Times, 2019). Meanwhile another orangutan charity witnessed an adoption increase of over 350\% during the November and December 2018 period (pers. comm.), with some supporters explicitly linking the decision to adopt to their children's distress about palm oil impacts.

While Rang Tan was undeniably influential, there were also broader sentiments at play. This article tackles the question of why some consumers, in the UK and across the Global North, are so consumed by palm oil. Firstly, I contend that anti-palm oil sentiments, while predominantly grounded in fears of orangutan extinction, emerge largely in spite of, rather than because of, the actions of orangutan charities, and are often at odds with the views and actions of orangutan conservationists. Secondly, I explore why, given this discrepancy between orangutan charities and their supporters, palm oil in particular has become transformed into a widespread matter of concern. I speculate that this emerges from how palm oil is mobilized as a metonym for human greed and wanton capitalist destruction. Consequently, this metonymic relationship mirrors broader Anthropocenic framings of human-nature relations, which emphasize humanity as a universal actor, and consequently species-level guilt. Thirdly I propose that the practices of 'species guilt' perpetuated through these 
narratives of palm oil destruction and orangutan suffering largely mitigate against a decolonizing model of conservation, as they have the potential to elide or deny agency to workers and villagers who are deeply enmeshed within the oil palm economy. In an effort to mitigate such tendencies while appreciating the positive actions of orangutan supporters, I conclude by recognizing the unintended value of palm oil boycotts in terms of agency and ecological consciousness and I address the potential to align such boycotts with a decolonial analysis, through centering the human dimensions of orangutan conservation.

This research contributes empirically to the existing consumer attitudes literature through in-depth qualitative examination of palm oil abstention beliefs and practices, rejecting the presumption of a utility maximizing rational consumer (still prevalent in said literature). Conceptually it expands upon existing work through situating consumer practices in the context of wider ethical dilemmas regarding human-nature relations, while also recognizing the moral ambivalences of the global political economy of palm oil. As a further analytical contribution, it attempts to bridge between literature focused upon palm oil consumption and oil palm production, drawing on political ecological accounts of people involved and impacted by the latter and attempting to put their perceptions in dialogue with understandings of Global North consumers. It seeks theoretically to contribute to the work of decolonizing conservation through addressing a current gap in knowledge regarding the diverse motivations and worldviews of conservationists (Kiik, 2018), particularly conservation supporters, while also recognizing the challenges some of those worldviews pose to a decolonizing approach.

This article also engages with ideas of the Anthropocene - the proposed new geological epoch in which humans have a defining, decisive and destructive impact upon planetary systems - which are increasingly permeating the natural and social sciences and public sphere (Chua and Fair, 2019). Dominant Anthropocene discourses, such as those generated by members of the Anthropocene Working Group within the International Union of Geological Sciences (Steffen et al., 2011), have been critiqued for treating humanity (or 'the Anthropos') as a singular universal subject and thereby eliding historical and contemporary inequalities in terms of responsibility for, and exposure to, ecological crises (Bonneuil and Fressoz, 2016). Alternative nomenclatures have been suggested, from Capitalocene (Moore, 2015) and Plantationocene (Haraway, 2016) to Anglocene (Bonneuil and Fressoz, 2016), as different means of designating the major actors and events responsible for our current ecological condition and thereby fragmenting and particularizing the figure of the Anthropos. Despite the prevalence of this critique within social science, the homogenizing figure of the Anthropos is still present in some conservation discourses, reflected in invocations of a collective species-level 'we.'

\section{Methodology}

This research was conducted in partnership with two UK-based charities that manage orangutan rescue and rehabilitation projects in Indonesian Borneo. I conducted a year of part-time participant observation through volunteering with one of the charities (2018-2019), in addition to 54 qualitative, in-depth, semi-structured interviews with orangutan conservation supporters. Interviewees were recruited via the two charities, who advertised the research to all their virtual 'adopters.' All advertisement respondents were invited to interview, with $64 \%$ undertaking an interview (all of which, barring three that were held face-to-face in London, were conducted digitally or telephonically). The interviews addressed the supporters' motivations for donating to orangutan conservation, how they understood the main threats orangutan populations faced, what other causes and charities they supported, and other ways in which they engaged with animals and ecology, beyond charitable giving. Interviewees were asked about whether they had seen the Rang Tan commercial, as well as whether they intentionally avoided knowingly purchasing and consuming products containing palm oil. Interviewees were not explicitly asked about their perceptions of oil palm workers or of communities who neighbored orangutan habitat; instead, these reflections emerged in many discussions. All interviews were recorded and anonymized, following the written consent of participants, and then fully transcribed and qualitatively coded using Nvivo.

In this article I predominately refer to 'British conservation supporters' as $74 \%$ of the interviewees were UK-based, but overall the sample more broadly drew from the Global North, with the vast majority of the 
remainder spread across the United States (11\%), continental Europe (7\%), and Australia and New Zealand (6\%). Some $90 \%$ of interviewees were white, and spanned a broad range of ages and diverse socio-economic backgrounds. Female respondents totaled $80 \%$, reflecting research that suggest UK-based women are more likely to donate to charities (Piper and Schnepf, 2008). Moreover, according to Piper and Schnepf, women are significantly more likely to support animal welfare organizations than men, and are slightly more likely to support environmental or conservation causes. The first charity - despite the conservation dimensions of its work - can be classified primarily as an animal welfare organization, due to its primary focus on the treatment of a range of charismatic megafauna. This is reinforced by the wider philanthropic interests of this charity's supporters, which coalesced around other animal-orientated charities, those focused on domestic pets and endangered species overseas, and this suggests again that the gender demographics of this study's participants were reflective of wider trends in charitable donation. Meanwhile the second charity, with its greater emphasis on ecosystem protection, can be more accurately classified as a conservation organization, and correspondingly its supporters showed more philanthropic interest in local ecology initiatives than animal-orientated charities.

This research is ethically and methodologically committed to principles of collaboration, reciprocity and respect. I have enacted these principles through working collaboratively with the charities to develop interview questions and lines of enquiry of interest to them, producing reports, recommendations and insights that can directly improve their working practices, and respecting and valuing the contributions of all interviewees, recognizing both the need to understand the complexity of why people support wildlife conservation (Kiik, 2018) and acknowledging the importance of small acts of support by individuals (Chua, 2018).

\section{Palm oil: human and ecological impacts and existing consumer perceptions}

To contextualize my research participants' anti-palm oil sentiments, I begin by introducing some of the major contentions surrounding palm oil's environmental and livelihood impacts, and existing analyses of consumer responses to it.

The negative ecological impacts of mass conversion of forested land to oil palm plantations are well documented. In West Kalimantan, Indonesian Borneo, conversion to oil palm was responsible for $27 \%$ of deforestation and $40 \%$ of peatland deforestation (Carlson et al., 2012). Indeed Indonesia had the highest rates of deforestation globally in the early 2010s (Margono et al., 2014). Conversion of tropical forest to oil palm results in average losses of 187 tons of above ground carbon per hectare, in addition to yearly carbon emissions of 10-15 tons/ha when on peatland (Reijnders and Huijbregts, 2008). Increased oil palm cultivation is also linked to biodiversity loss, as plantations support far fewer species than forested areas and lead to habitat fragmentation (Fitzherbert et al., 2008). This poses a significant threat to orangutan populations, especially given that Malaysia and Indonesia (the only countries to which orangutans are native) are the leading exporters of palm oil (Carter et al., 2007).

The social impacts of large-scale oil palm cultivation are varied. Palm oil plantations can be associated with economic and infrastructural development, including new roads and consequently access to markets and public amenities. However, as highlighted by feminist political ecologists, their introduction can also be very damaging to the lives of indigenous women (Julia and White, 2012) due to the impacts upon their tenure rights, the gendered division of labor in terms of household responsibility for subsistence and the undermining of women's other sources of income through loss of access to forest resources. Women tend to be employed by the plantation in roles that are more precarious and dangerous than those of men, working as day laborers spraying chemicals and fertilizing crops. Plantation work can reduce the time women have available for social activities, personal care or rest, as well as decreasing household food security (Mingorría et al., 2014). Elmhirst et al. (2017) have sought to refine this analysis, through highlighting how the impacts on women vary depending on their structural positions, particularly their mode of incorporation into the oil palm economy and land holding status. These impacts are also shaped by religion and their relationship to different modes of land tenure (Acciaioli, 2008). Often the creation of oil plantations leads to a long-term process of dispossession and escalating inequality over generations, as land scarcity increases for those in plantation zones (Li, 2017), and many villagers are excluded from plantation work due to their ethnicity, age or gender. Overall, Li concludes that while some benefit financially, the introduction of plantations overwhelmingly leads to impoverishment. 
There has been militant opposition to the opening of oil palm plantations at sites in Central Kalimantan (Acciaioli, 2008), due to contamination of water resources leading to skin diseases and decrease in fish populations in addition to the wider loss of access to land. These acts of resistance include demonstrations, theft, destruction of machinery, absenteeism and the burning of palms (Potter, 2009).

In addition to the immediate ecological and human impacts of expanding oil palm cultivation, consumer attitudes towards palm oil are also subject to increasing examination. Existing research conducted largely in the fields of environmental sustainability and consumer behavior suggests that concerns over palm oil consumption are not unique to the UK. There is evidence of active and passionate anti-palm oil activism in the US, France and Australia (D'Antone and Spencer, 2015), with a petition to Food Standards Australia and New Zealand for mandatory palm oil labelling receiving over 160,000 signatories (Pearson et al., 2014). Some 41\% of British consumers surveyed perceived palm oil as 'environmentally unfriendly' (Ostfeld et al., 2019), while 60\% of German consumers had negative associations with palm oil, and 40\% had previously searched lists of ingredients for it (Gassler and Spiller, 2018). Taylor et al. (2016) found that over 40\% of respondents surveyed in greater Melbourne, Australia (which has a population of 4 million), had intentionally purchased palm oil free products in the past year, while by contrast $15 \%$ had actively given to a wildlife charity that supports orangutans in the same time period. While my participants are all active charity supporters, this suggests that anti-palm oil sentiment extends beyond those who are already financially committed to conservation.

There is also evidence of low consumer demand for certified 'Roundtable on Sustainable Palm Oil (RSPO)' products, with poor recognition of the RSPO trademark (Gassler and Spiller, 2018), and mistrust of the RSPO process. Many consumers did not want the ethically and sustainably produced palm oil that RSPO certifies, but had a strong preference for no palm oil being present at all (Hinkes and Christoph-Schulz, 2019). This preference has resulted in some manufacturers actively asking for RSPO labelling to be removed from their packaging to avoid alerting consumers of the presence of palm oil, certified or otherwise (Larsen et al., 2018). This limited endorsement of RSPO certification mirrors broader social scientific critiques of the scheme. For instance, Ruysschaert and Salles (2018) argue that the RSPO have not been effective in curbing deforestation, despite increased engagement by conservation NGOs, due to the constrained manner in which NGOs attempt to exert influence.

While highlighting the scale of the phenomenon, the literature gives limited insight into why consumers actively reject palm oil in this way. As an exception, Hinkes and Christoph-Schulz (2019) found that German focus groups saw the major concerns about palm oil production were deforestation and biodiversity loss, although the working conditions and exploitation of smallholders were also noted by some participants. By contrast personal health concerns were the main motivation for reducing palm oil consumption among Italian consumers (Verneau et al., 2019).

Overall, these studies lack a richer qualitative analysis of the beliefs and values underlying consumers' anti-palm oil preferences, or an indication of actual consumer behavior as opposed to their hypothetically stated intentions (Verneau et al., 2019). Moreover some, such as Taylor et al. (2016) and Pearson et al. (2014), uncritically presume a linear relationship between reducing palm oil consumption and orangutan survival (which will be problematized in the following section), although Hinkes and Christoph-Schulz (2019) do highlight concerns that alternatives to palm oil may pose even greater sustainability challenges. My contribution is to bridge political ecological analyses of oil palm production and market and food-policy orientated studies of palm oil consumption. I also address the lack of in-depth qualitative research into palm oil abstention beliefs and practices, while also recognizing the moral ambivalences of the global political economy of palm oil.

\section{Pragmatic collaborations and orangutan conservation}

Having highlighted the prevalence of negative consumer responses to palm oil, bolstered in the UK by the circulation of the Rang Tan video, I turn now to the potential conflict between these sentiments and the stance of some conservationists. Many orangutan charities were less pleased than one might expect by the wave of public attention brought to the relationship between palm oil and habitat destruction inspired by the Rang Tan video. Rather than outright antagonism, many orangutan charities and conservationists work in pragmatic collaboration with palm oil corporations. During fieldwork I heard reports of some charities removing 
orangutans from oil palm concessions, training oil palm employees in how to handle orangutan encounters, receiving payment for their services (Palmer, 2020, 173-178), encouraging corporations to create forest corridors through their lands (Ancrenaz et al., 2016), and even reportedly sharing offices with these corporations. The Orangutan Land Trust currently lists two palm oil corporations as strategic partners (Orangutan Land Trust, n.d.), and advocates for palm oil over alternative vegetable oils due to oil palm's greater land use efficiency in terms of yield (De Vries et al., 2010). Scientists have been receiving significant research funding in order to investigate how to increase biodiversity on oil palm plantations without reducing yields (Rochmyaningsih, 2019) and have called for oil palm companies to play a greater role in orangutan conservation (Meijaard et al., 2012). Some orangutan conservationists openly oppose the demonization of palm oil, instead advocating for nuance and the recognition of potential economic benefits, collaboration and pragmatic improvements to oil palm cultivation practices (Meijaard and Sheil, 2019). These moves are allied to a broader focus on the viability of orangutan populations in anthropogenic landscapes, as opposed to concentrating solely on those in primary forest (Hockings et al., 2015). All of this suggests an approach to conservation less invested in notions of wilderness and purity.

Total boycotts of all palm oil (as opposed to RSPO certified palm oil) have not been endorsed by orangutan charities partly because they would disrupt these working relationships between orangutan charities and palm oil corporations. In 201947 zoos and conservation organizations who work with orangutans signed an open letter encouraging the development of more sustainable palm oil, and explicitly rejecting a blanket boycott (Chester Zoo, 2019). Blanket boycotts have also been accused by some orangutan conservationists of being polarizing and harmful, based on public misconceptions (Ancrenaz et al., 2016, p. 2). As I witnessed in my fieldwork, orangutan charity employees are sometimes forced into the unexpected position of defending palm oil to their supporters and highlighting that it is the deforestation that precedes it, not palm oil itself per $s e$, that is the source of the orangutan's worries. For instance, in the name of orangutan conservation, a UKbased organic vegetable box delivery company decided to go officially palm oil-free and consequently asked for a supportive quote from the small orangutan charity where I conducted fieldwork. The vege-box company's website then published a new section on palm oil, attributing co-authorship to the orangutan charity, and consequently presenting them as boycott advocates. Somewhat awkwardly, the orangutan charity had to ask for their name to be removed as they did not have the political license nor the desire to stand on a fully anti-palm oil platform. Consequently, the fervent anti-palm oil sentiment expressed by many orangutan supporters in the UK is actually emerging in spite of, rather than because of, the actions of the major orangutan charities.

\section{Palm oil: bodily complicity and metonymic power}

Given this discrepancy between the anti-palm oil enthusiasm expressed by so many orangutan supporters on the one hand and the delicate and pragmatic everyday relations between orangutan charities and palm oil corporations on the other, what is it that makes palm oil so distinctly antagonizing for British consumers compared with other ecologically destructive products? To answer this, I begin by examining my interviewees' engagements with palm oil, recognizing the power and agency palm oil seems to wield through manifesting in apparently innocuous items, and forcing a bodily connection with orangutan suffering. I focus on perceptions of it as insidious, invasive, and cheap. I then explore how this substance begins to accrue further meanings, investigating how palm oil is mobilized as metonym for human greed and capitalist destruction. Palm oil operates as both metonym and synecdoche, i.e., it is substituted for something it is associated with, and stands in for a larger whole of which it forms a part.

Palm oil was a significant yet far from straightforward matter of concern among my research participants. Of the 54 interviewees, 83\% actively made efforts to avoid palm oil: many had resorted to baking their own bread, printing out palm oil labelling guides to use while navigating supermarkets, making and selling their own palm-oil free soaps to fundraise for orangutan conservation or making their entire café business palmoil free. Only $16 \%$ of those actively avoiding palm oil (13\% of the overall number of interviewees) consciously opted for RSPO certified or otherwise sustainably certified products, mirroring the previously noted lukewarm consumer reception of the scheme (Hinkes and Christoph-Schulz, 2019). Meanwhile, 28\% expressed strong reservations about the effectiveness of the RSPO certification process, with uncertainty about how genuinely 
sustainable the products were or having concerns that the scheme enabled corporate 'greenwashing'. Many of those boycotting or avoiding palm oil to greater or lesser extents acknowledged the dilemma of oil palm being more space-efficient than equivalent oil producing crops, recognizing that alternatives may merely geographically shift or exacerbate the existing problem. A significant proportion of interviewees were also vegan $(13 \%)$ or vegetarian $(15 \%)$ for both ecological and animal welfare reasons, and many of them acknowledged that palm oil was often used as an animal product substitute due to its stability at room temperature, leading to further 'sustainable consumption' dilemmas. On a personal level, many interviewees acknowledged the negative impact on their time, finances and personal food preferences of actively avoiding products containing palm oil. Consequently, passionate palm oil avoidance did not emerge through denying the challenges, contradictions and limitations of engaging in sustainable consumption, but rather as an attempt knowingly to reckon with those complexities.

Versatility and ubiquity appear central to what made palm oil, as a substance, so morally repugnant and its avoidance so compelling. Palm oil is in countless everyday packaged goods. As Rudge and Ehrenstein(2021) argue, palm oil's proliferation as an ingredient was enabled through hydrogenation and chemical purification that rendered a nutty-tasting red oil bland and pale. Thus, its versatility and ubiquity is contingent upon its invisibility. Due to the range of derivatives produced from it, palm oil can appear under multiple guises, including over 200 ingredient names that may, but do not necessarily, include palm oil (Orangutan Alliance, n.d.). This thus creates uncertainty and, for some consumers, a hidden and almost deceptive omnipresence. As one interviewee framed it:

You imagine for a long time, 'I can boycott palm oil'. That is nice and easy. Then of course you realize that it is not just a question of it popping up in a few things, but the fact that it is everywhere and the sense of absolute complicity when I realized how many products I bought on a daily basis which had palm oil. (Interview 34)

The combination of its ubiquity, and its concealment through vague and obscure synonyms, seemingly forced consumers into an almost inevitable if unintentional relationship of complicity with rainforest destruction. While many interviewees actively supported numerous animal charities, for some the personal guilt and direct responsibility they felt for orangutan extinction through their palm oil consumption appeared to be a significant motivation for their charitable support of this particular species. For many the plight of the orangutan lent itself to a narrative of linear and unmediated connection, of "logging + oil palm $=$ no orangutans" (Interview 37), absolved, for instance, of the temporal and geographical displacements and delays of anthropogenic climate change.

As found in other studies (Hinkes and Christoph-Schulz, 2019; Verneau et al., 2019), many consumers placed greater emphasis upon abstaining from purchasing or consuming palm oil as an ingredient in food products, as opposed to its use in cosmetics or biofuels. Some interviewees openly recognized that their boycott fell short at the point of toiletries, explaining, for instance, "I do buy shampoo and I know it's got palm oil in it. I do buy it; I can't lie and say I don't because I do" (Interview 43). I attribute this greater concern regarding food to the intimately visceral relationship with palm oil generated through eating it, as palm oil's deceptive metamorphosis enables repeated, insidious corporeal invasions. Some interviewees even drew parallels between palm oil avoidance and vegetarianism, conjuring palm oil as a metonym for orangutan flesh:

It's not like we need it. This is why I went vegetarian. I think I probably got traumatized by one too many videos of screaming, dying animals and I just thought do you really need to put that in your mouth?... It's just completely unnecessary and that's what saddens me the most about what's happening with orangutans and deforestation is this is all absolutely unnecessary. But long-term completely damaging. And if I ever have kids, they might not even know what an orangutan is because my generation ate them to death basically for no good reason and didn't even realize we were doing it. (Interview 1) 
Returning to the doubt and uncertainty surrounding RSPO certification, some of the resistance towards sustainable palm oil can also be attributed to consumer's affective desire to purge themselves of palm, maintaining their body as one of few spaces free from the oil's incursions, aligning with the 'dreams of purity' that saturate palm oil's history of production and consumption (Rudge and Ehrenstein, 2021). As one interviewee pondered:

And even though it says that it's sustainable, I feel like it doesn't really matter. It's still palm oil. (Interview 25)

Central to the denunciation of palm oil was a concern with cheapness, of palm oil itself, of the products it was in, and consequently the cheapening of human and non-human life. For a number of interviewees, this mirrored a larger concern about alienation from processes of industrial food production, as processed foods or junk foods were held to blame. As one supporter explained:

Orangutans are one of our closest relatives and here we are killing it for cheap palm oil, for cheap vegetable oil just so we can eat cheap junk food. We could all break our addiction to cheap vegetable oil and eat better food. We would all be better off for it and we wouldn't be killing orangutans to do it. (Interview 45)

Many of the interviewees most confident in their ability to evade palm oil consumption emphasized their cooking of fresh whole foods and general avoidance of potentially palm oil-containing ready meals. This speaks to the wider practices of ethical consumption in which palm oil avoidance is embedded. Among the different consumption concerns, eating organic food when it was possible and affordable was the most popular, shared by $26 \%$ of interviewees.

However, these alignments were also to some extent disrupted by Iceland's pledge to remove all palm oil from its own brand products (Iceland is a British budget supermarket chain specializing in frozen goods), as its presence encouraged a greater engagement with processed food (and its cheapness) in order to remain palm oil free. The company also wanted to challenge the association of ethical consumption primarily with middleclass consumers (Wier et al., 2008). Prior to the Rang Tan commercial, only two out of 40 UK-based interviewees regularly or occasionally shopped at Iceland, yet since the video's circulation a further thirteen reported more positive attitudes towards the frozen food chain, with five now actively shopping there for the first time. Many interviewees expressed surprise that it was Iceland, rather than a supermarket explicitly catering towards wealthier consumers, that had taken these steps, and acknowledged that they may have held 'snobby' attitudes towards Iceland's regular customer base, presuming that they were solely motivated by low prices.

This relationship to industrial food production and ultra-processed goods leads to the second major reason for the intensity of anti-palm oil sentiment: palm oil's metonymic potency. As Chao (2018a, p. 632) notes, this vegetable fat is "almost oversaturated with meanings that relate to its destructive effects." I contend that palm oil becomes a metonym for orangutan supporters' anger and anxieties about human greed and capitalist destruction in the time of the Anthropocene, through its association with profit-seeking and the alienation of consumers from food production.

Reiterating the concern with cheapness, interviewees often moved from the problem of palm oil to the need for a systemic change of the food system, away from a reliance on ultra-processed food or 'junk food.' Connections were also made between palm oil, deforestation and climate change:

I think if we weren't all consuming madly in the West and wanting all of these products then they wouldn't be attempting to grow more palm oil and whatever else they're growing over there to feed that growing market... So, I just think it's a problem that all of us need to start addressing and to me it's sort of tied to all those wider problems of climate change and what we're actually doing to the planet we live on. (Interview 22) 
Through these various connections and associations, palm oil began to explicitly operate as a metonym for human greed:

It is human greed, the fact that we want things a certain way, we want our food on tap. It is all supply and demand and that is about greed. It is not necessarily about what people need, it is what they want, what they desire. The reality is - and that sounds really fatalistic - I think it is doomed. I really do. I think what we are doing as a human race is decimating all our resources as it is. (Interview 32)

In our discussions interviewees flexibly rescaled between the greed of the individual who scoffs (eats) cheap biscuits, and the greed of the corporation who profits from our scoffing, both indifferent to the suffering they have caused.

\section{Palm oil and the (mis)Anthropocene}

At odds with these associations of palm oil with destruction and greed, Chao (2018b) highlights the relations of care and affective attachment between oil palm nursery workers in Sumatra and their seedlings, and how many adopt maternal dispositions towards the plants. While these relations of care are entangled with violence (both in terms of the selection and culling of seedlings, and the extinctions that the oil palm's proliferations are predicated upon), they also disrupt the straightforward metonymic demonization of oil palm. Crucially they also highlight previous unacknowledged actors. If these are the many meanings that palm oil becomes saturated with in a Western consumer context, what does that mean for people who live and work in and alongside the oil palm plantations, as well as in proximity to orangutan habitats? To explore this, I turn to orangutan conservation supporters' perceptions of Borneo's human inhabitants.

Many interviewees framed oil palm workers' actions in terms of economic necessity and highlighted the need for alternative means of livelihood, as well as celebrating the actions of frontline conservation workers. In some accounts this sat in tension with framings that exclusively centered Western agency or that had the potential to slide into a condescending paternalism, mitigating against a decolonizing approach to wildlife conservation. Underlying these framings, and the metonym highlighted in the previous section, were clear resonances between the perspective of many orangutan supporters and contemporary discourses of the Anthropocene. These Anthropocenic imaginaries included invocations of species-level blame for the plight of the orangutan, a reification of Nature/Culture boundaries that largely erased Indigenous communities, and misanthropic tropes of disgust at the over-populating and excessively consuming figure of the Anthropos. Consequently, I argue that in order to align anti-palm oil sentiments with a decolonizing approach to conservation, one must also tackle the Eurocentric assumptions present in many Anthropocene discourses.

Firstly, many interviewees framed oil palm cultivators and plantation workers sympathetically, recognizing that they were also subject to corporate exploitation and were acting out of economic necessity. Concerns were raised about the fairness of wages and the dispossession of Indigenous land. For some supporters recognizing their economic privilege vis-à-vis Indonesian laborers mollified any moral condemnation of the latter's actions:

I mean it's very easy for us in our warm comfortable homes and our well-fed lives to say, 'Oh you, naughty people, stop cutting down your trees and planting palm oil.' That's really hypocritical though 'cause we haven't got to live like that. (Interview 10)

Others empathized with the oil palm workers, recognizing a shared sense of precarity and loss of agency due to their mutual enrolment within a global capitalist system, while directing their critique at the oil palm corporations and the Indonesian and Malaysian governments. Linked to this, some articulated a sense of shared responsibility distributed between producers and consumers, fueled by Western market demand. For others 
though, this emphasis on economic necessity failed to stifle their visceral fury at those complicit in deforestation:

And you can't blame them because these are people who haven't got a living otherwise and they're human beings and a) they're devious and b) they're needy. They've got children the same as anybody else. But I do blame them, I hate them. But you shouldn't blame them and if I was in that situation, I'd probably... I don't know. (Interview 43)

Only a small minority of interviewees framed people who shared space with orangutans as deliberately cruel towards them. Yet an equally small number posited local people as positive, active contributors to orangutan conservation, largely through emphasizing their enormous respect and gratitude towards the kind and dedicated work of the orangutan rehabilitation center employees. Yet such a binary between the economically precarious yet ecologically destructive logger and the caring and courageous conservation worker does not necessarily hold. Many of those employed by the conservation and ecotourism industry have previously worked for timber or oil palm corporations, and shifted sectors due to the improved working conditions, or may have family members and neighbors who straddle both domains (Viola Schreer, pers. comm.).

Linked to the emphasis on economic necessity, another major theme was the need to engage with local people on their own terms. This broadly encompassed a wide variety of approaches, including ensuring that local people benefit from conservation, recognizing the fear that proximity to orangutans might engender or approaching orangutan conservation via another species that maybe more locally resonant, such as red river hogs (Potamochoerus porcus). Yet allied to this sympathetic framing, was a strong potential for paternalism (in some cases openly acknowledged). Many participants emphasized the need to educate local people, to encourage them to take pride in their natural surroundings.

I believe personally that - same as in Africa with the ivory trade - it is about educating the people there and trying to make them understand - it sounds really bloody patronizing, this - trying to get them to remember, not understand, that a) it is their culture and b) it is their wealth. These are the jewels in their crown, not ours. They should love their animals. (Interview 32)

Yet whether framed in a more sympathetic or incensed mode, these representations of local people often denied them agency, and in some cases centered agency on Euro-American consumers.

If you stopped and asked these people why they're cutting down forests and planting these trees to make palm oil, they'd go, 'Because he told me to.' And that's it, that is the only reason they do it. We in the UK or in the countries that we sit very fortunate in, we are the only ones that can make a change. (Interview 44)

This explicit centering of European actors clearly resonates with some contemporary Anthropocene narratives, which in their emphasis on a singular figure of 'the Anthropos', subsume all of humanity under a White EuroAmerican subject position. Paralleling these Anthropocenic discourses, a majority of participants engaged with 'species-level thinking' and 'species guilt', including invocations of the general Human 'we.'

It is a shame, because we as humans are doing the damage. We're the ones killing them in a way really. (Interview 2)

While these invocations of species guilt emerged in at least half of the interviews, some accounts mobilized the universal 'we' to position themselves directly in the place of villagers who had taken orangutans 
as pets, or nimbly switched back forth between the intimate 'we' of a family unit and the ahistorical and geographically ungrounded collective 'we' of humanity.

Just very upset about what we're doing to the planet, what we're doing to other species, and you just feel like you want to kind of give something back...if we've caused this suffering then we owe them a life kind of thing. So, if we've had an orangutan chained up as a pet somewhere for long enough that it can no longer be rehabilitated as a wild animal then we owe him or her the chance to at least have as natural or as happy [a life] as is possible. (Interview 28)

Bolstering this universalization of responsibility for orangutan conservation was a lack of geographical specificity in many interviews. While for some participants their concerns for orangutans emerged through having visited Borneo or through a personal connection to Indonesia, for many, the orangutan was presented as abstract and geographically unmoored. In $28 \%$ of interviews, no acknowledgement was made of where in the world orangutans were found, with some statements obliquely circumventing this question, through referring, for instance, to how "change is happening so quickly in that part of the world" (Interview 50). This loss of geographical specificity helps to elevate the orangutan to the status of a global commons to be preserved, as well as aligning with an Anthropocenic imaginary of globalized Nature as imperiled by a homogenous Humanity.

Permeating through expressions of sympathy or paternalism towards workers and villagers in Borneo was a broader misanthropic denunciation of the actions of the Human. Ecological destruction, while lamented, was presented by some as an inevitable and naturalized teleological process, linked to a misanthropic and somewhat hopeless vision of humanity as inherently greedy and selfish.

Human beings need to stop being so greedy. I just think that's the baseline...we need, as human beings, to stop looking around us at all these things that we think we should own and look at the thing that we're actually destroying. But I think human beings think it will never happen in our lifetime, the planet will never disappear in our lifetime, but in somebody's lifetime it will disappear. (Interview 44)

Some interviewees portrayed humans as 'disgusting', or as 'monsters swarming over the land', and comparable to an excess of bacteria that is poisoned by its own excrement. Some expressed explicit, if sometimes joking, anti-human sentiments.

Honestly, I would be very happy if humans were annihilated. I feel that strongly and all my animal/environmental friends think exactly the same. We have caused such destruction for an intelligent creature that I don't think we have the right to live any more. The way we are going, we are going to kill ourselves off, which would be great. Then hopefully the planet will rest in peace, and they can rejuvenate. (Interview 33)

These sentiments were often allied with neo-Malthusian concerns regarding unmanageably high human populations, with interviewees emphasizing the need for significant limits on population growth in order to create more space for other species to flourish.

I'm talking about a widespread education program so that people understand that as a species... and we are, after all, just a species. We can't keep creating more of ourselves at the rate that we are if we're to survive as a species and the rest of the planet's species are going to survive. (Interview 10) 
These narratives speak to an underexamined relationship between concern and affection for nonhuman life and anger and resentment towards the actions of humanity. While Searle and Turnbull (2020) have noted the connection between narratives of nature's resurgence and description of humanity as a virus in the context of the COVID19 pandemic, further work remains to be done to unpick and understand the specific intellectual genealogies and cultural histories of anti-human sentiments among some environmentalists and conservation supporters.

In the orangutan supporters' accounts, Humanity as a homogenous category was often invoked, rather than differentiating between the ecological impacts of different individuals and societies. As a final dimension of the Anthropocene imaginary, forests were repeatedly represented as absent of people, rendering Dayak communities invisible and reinforcing Nature/Culture dualisms.

It's very upsetting to think that humans have just invaded their space and we have no right to be in their space, it's their world and it's just so wrong. (Interview 40)

Returning to the opening vignette, Rang Tan's story also encourages a universalizing, essentializing and misanthropic vision of humanity. As Rang Tan tells us "There's a human in my forest and I don't know what to do. He destroyed all of our trees for your food and your shampoo." Again, the forest is conveyed as a space of nature separate from the human that renders invisible human communities, both Indigenous and migrant, who also call the forest home. While the final refrain refers to humans in the plural, for the majority of lines the human actor in question is singular and gendered male. It is not the timber corporations or the palm oil industry of the complicity of the Indonesian government that has destroyed Rang Tan's home, but the Anthropos himself.

However, this vision of the Anthropocene was disrupted by some accounts. A few participants refused to blame the unitary figure of the Anthropos, instead emphasized capitalism and corporate power as being responsible for the current ecological predicament, with one interviewee rejecting a species-level view in favor of a critique of the $1 \%$.

I think as the human race, we... I say the human race. The fact is for me, it is a very small number of humans that are making the decisions that matter. There are some big global companies and politicians and all kinds of people in positions of power where money seems to outweigh what is right for the planet moving forward. (Interview 26)

This forces a recognition that there is not one singular narrative of the Anthropocene (Bonneuil and Fressoz, 2016), and instead many stories can be told of it, under many different names (from Capitalocene to Plantationcene to Chthulucene), which align to different assignations of responsibility and blame. While many participants emphasized species guilt, they were also quick to highlight the complex configurations of actors involved, from oil palm corporations and their employees to the governments of exporting and importing nations and their insufficient regulations, to even the unloving other of oil palm itself (Chao, 2018a). Moreover, despite these glimpses of misanthropy, many interviewees were far from solely biocentric in their concerns. $44 \%$ of interviewees also gave to humanitarian, health and disability charities, with nearly $10 \%$ actively volunteering with human-focused causes. Thus, engagement with certain Anthropocenic tropes does not preclude concerted acts of intra-species compassion.

I contend that there are ways of recognizing the potency and metonymic compulsions of palm oil, without reiterating an exclusionary and Eurocentric vision of the Anthropos. Consequently, I now seek to bridge the gaps between these accounts of palm oil's non-consumers and those of oil palm's workers, as well as acknowledging the merits of these acts of palm oil abstention, even while they may be at odds with the stances of many orangutan charities. 


\section{Decolonizing conservation}

While current palm oil discourses are forcing a reckoning with everyday ingredients and their relationships to global supply chains and ecological destruction, some interviewees' accounts still center EuroAmerican consumer agency in a mode which demonizes or renders invisible those who share space with orangutans, many of whom are economically depend on oil palm. This is at odds with attempts to decolonize conservation, which involves recognizing that many of the practices, paradigms and values underpinning mainstream biodiversity conservation are not inherent or universal but are geographically and historically contingent products of Western nations, intertwined with histories of imperialism and dispossession. This is particularly key in the case of orangutan conservation, due to the colonial legacies and practices of domination that continue to shape it (Parreñas, 2018). A decolonizing approach to conservation seeks to recognize those marginalized by conservation and to bring a greater variety of knowledges and means of apprehending the world into wildlife conservation. For orangutan conservation in particular, this involves rejecting an antagonistic binary of Humans and Nature and acknowledging the significance of people who share space with orangutans, including farmers, conservation employees and plantation workers.

One of the first steps towards this could be the recognition of points of connection between people at different nodes of the oil palm supply chain, and rooting these connections in geographical specificity, rather than in abstract universalism. Here I deploy Chao's (2018a) research with the Marind people of West Papua whose lands are surrounded by expanding oil palm plantations. It is apparent that a relationship of inevitable complicity through consumption is also shared by those on the frontlines of oil palm destruction. Chao's interlocutors are aware that despite their hatred of palm oil, they still consume it every day in biscuits, ketchup and soap. Its insidious nature is again enabled by its use of many disguising names. As one of them explains "Sawit [oil palm] is everywhere, but it keeps its secrets well" (2018a, p. 628). Moreover, while those who live alongside the oil palm are often absent in the orangutan supporters' accounts, the distant consumers of palm oil were a noted topic of interest for the younger Marind that Chao worked with, reframing the Global North consumer as an object of attention, rather than as a subject of action.

The metonymic potential of palm oil is also apparent both to Global North consumers and those who live in "plantation zones" ( $\mathrm{Li}, 2017$, p. 1159). Similar to the orangutan supporters, some of the Marind also invoke oil palm as an emblem of destruction (Chao 2018a). Drawing upon her interlocutors' testimonies, Chao depicts oil palm as an "unloving" other and "agentive plant-person of radically destructive inclinations" (2018a, p. 622), who obliterates the community members' past, present and future. Palm oil is situated as outside the Marind world of reciprocity and mutual flourishing, as oil palm is seen as being without kin and as a being of pure self-interest. Yet the metonymic operations are historically and geographically grounded, rather than relying on species-level thinking or abstract notions of Nature and the Human. For instance, for Chao's (2018a) interlocutors the oil palm embodies a further colonial imposition upon their lands, as they recount nightmares in which the trees are transfigured into armed Indonesian soldiers who shoot at or eat the Marind people. Consequently, the symbolic potency of oil palm can be recognized without replicating ahistorical and universalizing tropes of the Human.

People who work with and live alongside both oil palm and orangutans can be foregrounded by recognizing these parallels between those consumed with palm oil and those fearful of oil palm. Both charities that I conducted this research with were very receptive to this idea, with one centering 'people' as one of the three prongs of its work, and the other, after discussing my initial research findings, was keen to articulate a more nuanced and humanized picture of orangutan conservation and to tie in more international development concerns. This speaks to a wider move towards not seeing wildlife conservation and human-focused research and advocacy as inherently opposed, but instead as the basis for mutually transformative dialogue (Chua et al., 2020). Moreover, this vision was already shared by some of the interviewees, with for instance one observing that: 
We can want all we want but it's not up to us. It has to come from the people who live with them. And that's not always easy because I don't stand in my back garden and suddenly see a fullgrown male orang and if I did, I might have very different views about whether I liked orangs or not. (Interview 39)

Such a perspective is critical because it highlights not just the heterogeneity of oil palm, but of the orangutan itself, recognizing that some, but not all, anthropogenic deaths are motivated by fear (Davis et al., 2013), and that understandings of responsibility and stewardship towards orangutans are not a universal. This further complicates the metonymic enrolment of the orangutan in Anthropocene discourses.

\section{Conclusion}

This article has sought to understand why some British consumers are so 'consumed' by palm oil avoidance, and yet many orangutan conservationists reject a blanket boycott in favor of pragmatic negotiations with oil palm corporations. Firstly, palm oil, recognized as insidious, invasive and cheap, seems to wield significant agency through manifesting in apparently innocuous items and forcing a bodily connection with orangutan suffering. Secondly, it is mobilized as a metonym for human greed and capitalist destruction Yet this metonym can replicate Anthropocenic tropes of 'universal Humanity' that render invisible people who live alongside orangutans and palm oil plantations. This is at odds with attempts to decolonize conservation. Having understood why boycotts occur, the question remains: what good does consumer palm oil avoidance bring? One could argue that it in fact further imperils orangutan populations because it discourages palm oil companies from moving towards more sustainable practices (Meijaard and Sheil, 2019) and jeopardizes the livelihoods of those who depend upon the oil palm industry. On the other hand, these boycotts may have limited economic leverage as only $15.6 \%$ of palm oil imports globally are into the EU, with India, China and Pakistan also representing significant markets (USDA, 2020).

Perhaps palm oil abstention can be seen as one of many 'small acts' of good (Chua, 2018) performed by orangutan supporters. The vast majority of supporters I interviewed actively gave money, time and thought to a range of conservation and animal welfare endeavors. They did not just change their peanut butter brand, avoiding palm oil, to assuage their 'species guilt.' Many interviewees acted upon their 'response-ability' (Haraway, 2016) to nonhuman kin, by volunteering with local nature trusts, designing extinction-themed art, raising funds through sponsored walks, runs or haircuts, and caring for animals in their own lives, from the hedgehogs in their garden to ex-racing greyhounds.

For many participants their awakening of concern over biodiversity loss was coupled with interrogation of their own consumption practices. I contend that recognizing the ubiquity of palm oil and the near inescapability of one's complicity in its production forces a critical examination of our relations to food production and the more-than-human world. This happens even if the villainization of palm oil itself lacks nuance. It certainly eschews the geographical distancing and spatial displacement of ecological crises, and instead forces a reckoning with the inextricable entanglement of the human and the natural. Such a reckoning is not without limitations, and could be better married with decolonizing approaches to conservation that acknowledge those living and working alongside oil palm and orangutans. Yet perhaps the true value of palm oil avoidance lies in the sense of agency that it engenders, in terms of critically engaging with one's complicity with destruction, and the extension of this agency into other more immediate domains of care and compassion.

\section{References}

Acciaioli, G. (2008). Mobilizing against the 'cruel oil': Dilemmas of organizing resistance against palm oil plantations in Central Kalimantan. In G. Persoon \& and M. Ossewijer (Eds.), Reflections on the heart of Borneo (pp. 91-119). Tropenbos International.

Ancrenaz, M., Meijaard, E., Wich, S., \& Simery, J. (2016). Palm oil paradox: sustainable solutions to save the great apes. 2nd edition. UNEP / GRASP.

Bonneuil, C. \& Fressoz, J-B. (2016). The shock of the Anthropocene: The Earth, history and us. Verso. 
Carlson, K. M., Curran, L. M., Ratnasari, D., Pittman, A. M., Soares-Filho, B. S., Asner, G. P. et al. (2012). Committed carbon emissions, deforestation, and community land conversion from oil palm plantation expansion in West Kalimantan, Indonesia. Proceedings of the National Academy of Sciences of the United States of America 109(19), 7559-7564. https://doi.org/10.1073/pnas.1200452109

Carter, C., Finley, W., Fry, J., Jackson, D. \& Willis, L. (2007). Palm oil markets and future supply. European Journal of Lipid Science and Technology 109(4), 307-314. https://doi.org/10.1002/ejlt.200600256

Change.org. (n.d) Release Iceland's banned Christmas advert on TV \#NoPalmOilChristmas Retrieved April 9, 2020, from https://www.change.org/p/release-iceland-s-banned-christmas-advert-on-tvnopalmoilchristmas

Chao, S. (2018a). In the shadow of the palm: dispersed ontologies among Marind, West Papua. Cultural Anthropology 33(4), 621-649. https://doi.org/10.14506/ca33.4.08

Chao, S. (2018b). Seed care in the palm oil sector. Environmental Humanities 10(2), $421-446$. https://doi.org/10.1215/22011919-7156816

Chester Zoo. (2019, November 1). Protect wildlife: demand sustainable palm oil. https://www.chesterzoo.org/news/sustainable-palm-oil-statement/

Chua, L. (2018). Small acts and personal politics: on helping to save the orangutan via social media. Anthropology Today 34(3), 7-11. https://doi.org/10.1111/1467-8322.12432

Chua, L. \& Fair, H. (2019). Anthropocene. The Cambridge encyclopedia of anthropology. https://www.anthroencyclopedia.com/entry/anthropocene

Chua, L., Harrison, M.E., Fair, H., Milne, S., Palmer, A., Rubis, J., Thung, P. et al. (2020). Conservation and the social sciences: beyond critique and co-optation. A case study from orangutan conservation. People and Nature 2, 42-60. https://doi.org/10.1002/pan3.10072

D'Antone, S., \& R. Spencer. (2015). Organising for sustainable palm oil consumption: a market-based approach. Consumption Markets \& Culture 18(1), 55-71. https://doi.org/10.1080/10253866.2014.899217

Davis, J.K., K. Mengersen, N.K. Abram, et al. (2013). It's not just conflict that motivates killing of orangutans. PLoS ONE 8(10), Article e753753. https://doi.org/10.1371/journal.pone.0075373

De Vries, S.C., van de Ven, G.W., van Ittersum, M.K. \& Giller, K.E. (2010). Resource use efficiency and environmental performance of nine major biofuel crops, processed by first-generation conversion techniques. Biomass and Bioenergy 34(5), 588-601. https://doi.org/10.1016/j.biombioe.2010.01.001

Elmhirst, R., Siscawati, M., Basnett, B.S. \& Ekowati, D. (2017). Gender and generation in engagements with oil palm in East Kalimantan, Indonesia: Insights from feminist political ecology. The Journal of Peasant Studies 44(6), 1135-57. https://doi.org/10.1080/03066150.2017.1337002

Fitzherbert, E.B., Struebig, M.J., Morel, A., Danielsen, F., Brühl, C.A., Donald, P.F. \& Phalan, B. (2008). How will palm oil expansion affect biodiversity? Trends in Ecology and Evolution 23(10), Article 538e544. https://doi.org/10.1016/j.tree.2008.06.012

Gassler, B. \& Spiller, A. (2018). Is it all in the MIX? consumer preferences for segregated and mass balance certified sustainable palm oil. Journal of Cleaner Production 195, 21-31. https://doi.org/10.1016/j.jclepro.2018.05.039

Haraway, D. (2016). Staying with the trouble: making kin in the Chthulucene. Duke University Press.

Hickman, A. (2018, December 3). Iceland's Rang-Tan campaign delivers 65m views, sales and consideration lift. PR Week. https://www.prweek.com/article/1520088/icelands-rang-tan-campaign-delivers-65mviews-sales-consideration-lift

Hockings, K.J., McLennan, M.R., Carvalho, S., Ancrenaz, M., Bobe, R., Byrne, R.W., \& Dunbar, R.I.M. et al. (2015). Apes in the Anthropocene: flexibility and survival. Trends in Ecology and Evolution, 30(4), 215222. https://doi.org/10.1016/j.tree.2015.02.002

Julia and White, B. (2012). Gendered experiences of dispossession: oil palm expansion in a Dayak Hibun community in West Kalimantan. The Journal of Peasant Studies, 39(3-4), 995-1016. https://doi.org/10.1080/03066150.2012.676544 
Kiik, L. (2018). Conservationland: toward the anthropology of professionals in global nature conservation. Critique of Anthropology, 39(4), 391-419. https://doi.org/10.1177/0308275X18821177

Larsen, R. K., Osbeck, M., Dawkins, E., Tuhkanen, H., Nguyen, H., Nugroho, A., \& Wolvekamp, P. (2018). Hybrid governance in agricultural commodity chains: Insights from implementation of 'No Deforestation, No Peat, No Exploitation' (NDPE) policies in the oil palm industry. Journal of Cleaner Production, 183, 544-554. https://doi.org/10.1016/j.jclepro.2018.02.125

Li, T.M. (2017). Intergenerational displacement in Indonesia's oil palm plantation zone. The Journal of Peasant Studies, 44(6), 1158-1176. https://doi.org/10.1080/03066150.2017.1308353

Margono, B. A., Potapov, P. V., Turubanova, S., Stolle, F. \& Hansen, M. C. (2014). Primary forest cover loss on Indonesia over 2000-2012. Nature Climate Change, 4, 730-735. https://doi.org/10.1038/nclimate2277

Meijaard, E. \& Sheil, D. (2019). The moral minefield of ethical oil palm and sustainable development. Frontiers in Forests and Global Change, 2, 1-15. https://doi.org/10.3389/ffgc.2019.00022

Meijaard, E., Wich, S., Ancrenaz, M., \& Marshall, A. J. (2012). Not by science alone: why orangutan conservationists must think outside the box. Annals of the New York Academy of Sciences, 1249, $29-44$. https://doi.org/10.1111/j.1749-6632.2011.06288.x

Mingorría, S., Gamboa, G., Martín-López, B. \& Corbera, E. (2014). The oil palm boom: socio-economic implications for Q'eqchi'households in the Polochic valley, Guatemala. Environment, Development and Sustainability, 16(4), 841-871. https://doi.org/10.1007/s10668-014-9530-0

Moore, J.W. (2015). Capitalism in the Web of Life: Ecology and the accumulation of capital. Verso.

Orangutan Alliance. (n.d) Alternative names to Palm Oil. Retrieved April 21, 2021, from https://orangutanalliance.org/whats-the-issue/alternative-names-for-palm-oil/

Orangutan Land Trust. (n.d.) Our strategic partners. Retrieved June 21, 2020, from https://www.forests4orangutans.org/our-strategic-partners/

Ostfeld, R., Howarth, D., Reiner, D., \& Krasny, P. (2019). Peeling back the label-exploring sustainable palm oil ecolabelling and consumption in the United Kingdom. Environmental Research Letters, 14(1), 1-9. https://doi.org/10.1088/1748-9326/aaf0e4

Palmer, A. (2020). Ethical debates in orangutan conservation. Routledge.

Parreñas, J. S. (2018). Decolonizing extinction: The work of care in orangutan rehabilitation. Duke University Press.

Pearson, E.L., Lowry, R., Dorrian, J. \& Litchfield, C.A. (2014). Evaluating the conservation impact of an innovative zoo-based educational campaign: 'Don't Palm Us Off' for orang-utan conservation. Zoo Biology, 33(3), 184-196. https://doi.org/10.1002/zoo.21120

Piper, G. \& Schnepf, S.V. (2008). Gender differences in charitable giving in Great Britain. Voluntas, 19, 103124. https://doi.org/10.1007/s11266-008-9057-9

Potter, L. (2009). Oil palm and resistance in West Kalimantan, Indonesia. In Caouette, D. \& Turner, S. (Eds.). Agrarian angst and rural resistance in contemporary Southeast Asia (pp. 125-154). Routledge.

Reijnders, L. \& Huijbregts, M.A. (2008). Palm oil and the emission of carbon-based greenhouse gases. Journal of Cleaner Production, 16(4), 477-482. https://doi.org/10.1016/j.jclepro.2006.07.054

Rochmyaningsih, D. (2019). Courting controversy, scientists team with industry to tackle one of the world's most destructive crops. Science. July 12. https://www.sciencemag.org/news/2019/07/courtingcontroversy-scientists-team-industry-tackle-one-world-s-most-destructive-crops

Rudge, A. and Ehrenstein, V. (2021). Dreams of purity: improved palms, refined oils, and ethical consumption. Society and Space. Magazine, April 12, 2021. https://www.societyandspace.org/articles/dreams-ofpurity

Ruysschaert, D., and Salles, D. (2018). The strategies and effectiveness of conservation NGOs in the global voluntary standards: the case of the roundtable for sustainable palm oil. In Larsen, P.B. \& Brockington, 
D. (Eds.). The anthropology of conservation NGOs: rethinking the boundaries (pp. 121-150). Palgrave Macmillan.

Searle, A. and Turnbull, J. (2020). Resurgent natures? More-than-human perspectives on COVID19. Dialogues in Human Geography 10(2): 291-295. https://doi.org/10.1177/2043820620933859

Steffen, W., J. Grinevald, P. Crutzen \& McNeill, J. (2011). The Anthropocene: conceptual and historical perspectives. Philosophical Transactions of the Royal Society of London A: Mathematical, Physical and Engineering Sciences, 369(1938), 842-867. https://doi.org/10.1098/rsta.2010.0327

Taylor, S., K.K. Miller, and McBurnie, J. (2016). Community perceptions of orangutan conservation and palm oil in Melbourne, Australia. International Journal of Environmental Studies, 73(2), 255-267. https://doi.org/10.1080/00207233.2016.1144332

The Times. (2019, January 12). Banned TV advert triggers surge in orangutan support. The Times, 34.

USDA Foreign Agricultural Service. (2020). Oilseeds: world markets and trade (June 2020). Retrieved June 30, 2020 from https://www.fas.usda.gov/data/oilseeds-world-markets-and-trade

Verneau, F., F. La Barbera, M. Amato, \& Sodano, V. (2019). Consumers' concern towards palm oil consumption: An empirical study on attitudes and intentions in Italy. British Food Journal, 121(9), 1982-1997. https://doi.org/10.1108/BFJ-10-2018-0659

Wier, M., Jensen, K.O., Andersen, L.M. \& Millock, K. (2008). The character of demand in mature organic food markets: Great Britain and Denmark compared. Food Policy, 33, Article 406e421. https://doi.org/10.1016/j.foodpol.2008.01.002 